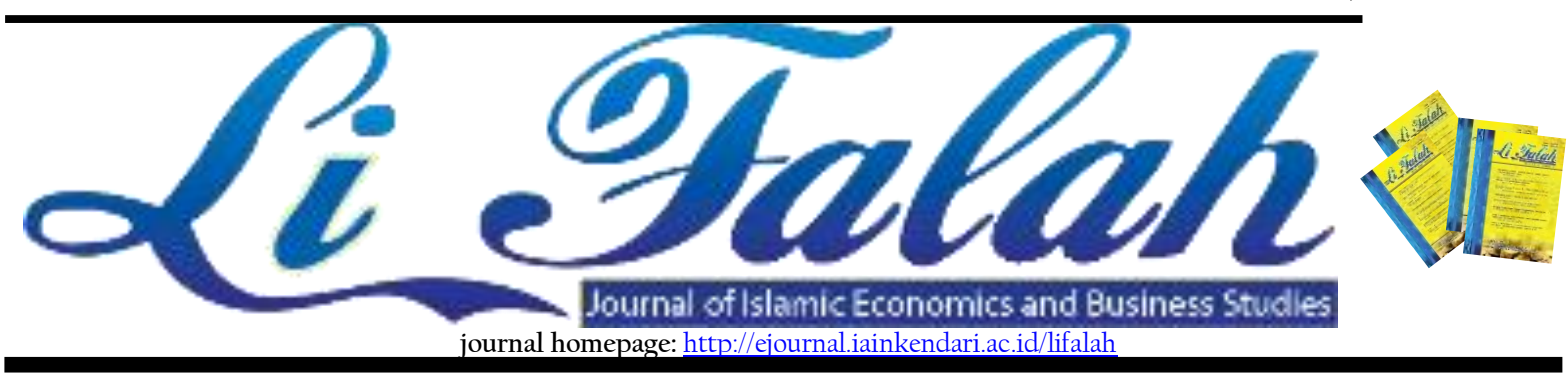

\title{
Establishment of Waqf to Alleviate Poverty Among Muslims in Oyo State South-West, Nigeria: Test of Theory of Planned Behaviour
}

\author{
Ibraheem Alani Abdulkareem ${ }^{1}$, Mohd Sadad Mahmud ${ }^{2}$, AbdulFattah \\ AbdulGaniyy ${ }^{3}$, Olanrewaju Atanda Aliu ${ }^{4}$ \\ ${ }^{12}$ Universiti Sultan Zainal Abidin (UNISZA), Malaysia \\ ${ }^{3}$ Department of Accountancy, Federal Polytechnic, Kaura Namoda, Zamfara State, Nigeria. \\ ${ }^{4}$ Department of Accounting, University of Ilorin Nigeria.
}

Email: ibraheemalanil@yahoo.com ${ }^{1}$; mohdsadad@unisza.edu.my²; abuaishah1425@yahoo.com³; alirawa@gmail.com ${ }^{4}$

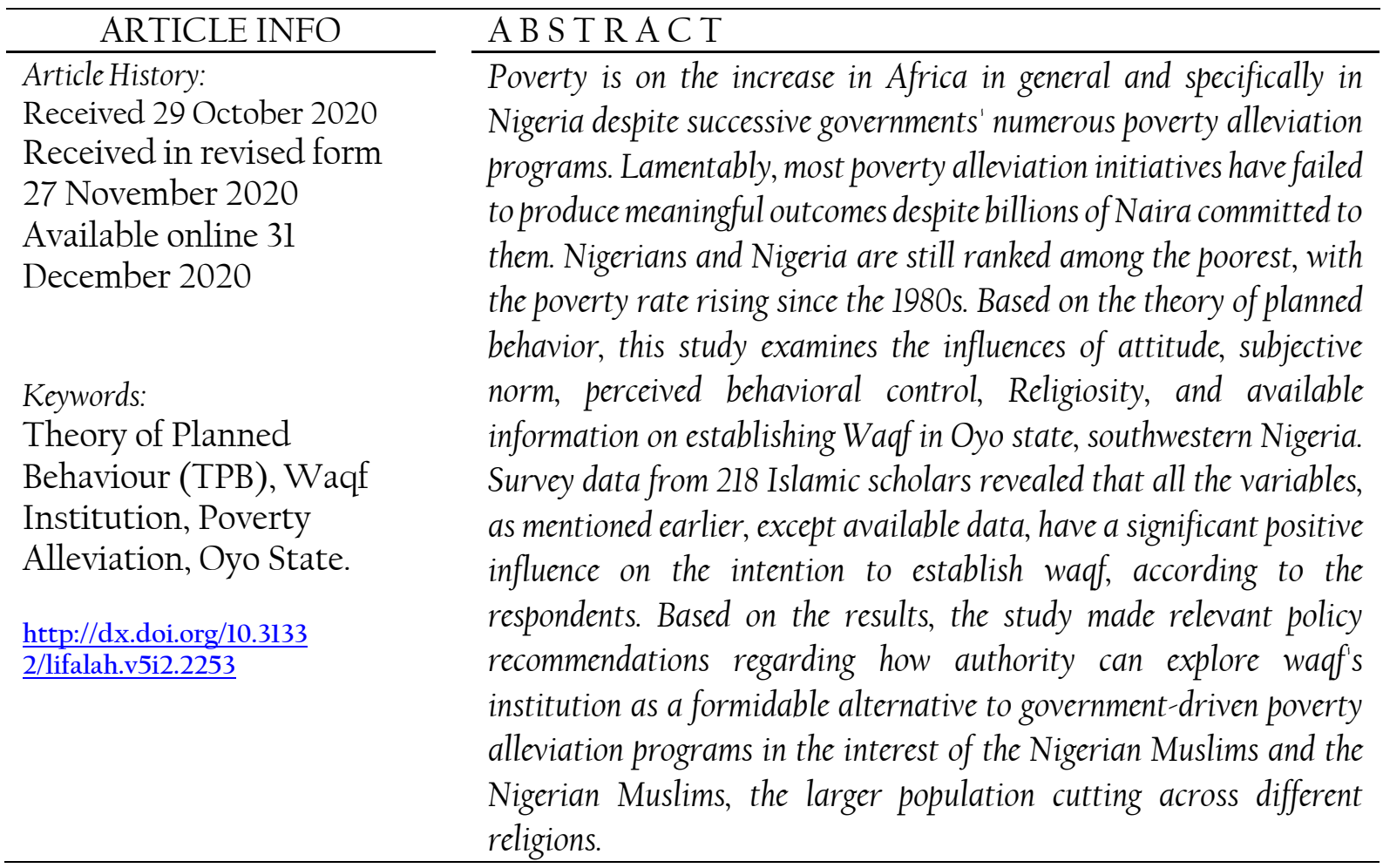




\section{Introduction}

In many regions of the world, poverty alleviation drives have yielded positive results with Africa's exemption, where poverty persistently ravages the inhabitants, leading to serious concerns. The current trends show that about 9 out of 10 extremely poor will be in Africa by 2030 (Ziyaviddinovna \& Sagdullaevich, 2020). In Nigeria, the most populous African nation, $70 \%$ of the population lives below the poverty level despite abundant human and mineral resources (Okoroafor \& Nwaeze, 2013). Thus, one of Nigeria's problems is poverty prevalence affecting a large percentage of the population. The effects of poverty on Nigerians have attracted authorities and scholars' attention to look for ways to combat the menace. In the last three decades, successive civilian and military governments have formulated and implemented different policies to alleviate the scourge of poverty among Nigerians. Lamentably, most poverty alleviation initiatives have failed to produce meaningful outcomes despite billions of Naira committed to them. Both Nigerians and Nigeria still ranked among the poorest, with the poverty rate rising since the 1980s (AbdulKareem, Ogunbado, AbdulGaniyy, \& Mahmud, 2019; Alaro \& Alalubosa, 2019). World Bank reports project that by 2050, Nigeria is set to become the world's third-biggest poverty-afflicted nation (Kazeem, 2018).

Reports and literature evidence have demonstrated that waqf is one of the powerful instruments to mitigate poverty. An excellent way to alleviate poverty is through the Waqf institution, which has played a significant role in overcoming poverty. Waqf institution is one of the Islamic alternatives aimed at bridging a sustainable gap between the rich and the poor within the holistic framework of brotherhood, mutual care, and concern for the psychophysical enrichment and survival of those in need (Ali, 2009). Waqf can eradicate poverty (Yusuff \& Nor Aziz, 2013) by caring for the underprivileged, regardless of their religion, sect, gender, tribe, or color.

Waqf has the objective of poverty alleviation, similar to Zakat. Waqf is instrumental in poverty alleviation. However, there is agreement among Islamic scholars that performing waqf is not compulsory compared to Zakat, which becomes mandatory on a Muslim when their wealth reaches a specific amount. Because of its voluntary status, this study proposes to examine the intention to establish waqf for poverty alleviation in Oyo State, southwestern Nigeria using an extended theory of planned behavior (TPB) with a sample drawn from the Muslim population. In addition to attitude, subjective norm, and perceived behavioral control specified as the determinants of intention in TPB, the framework of the study was extended with the inclusion of Religiosity and amount of information as influencing factors towards establishing waqf for poverty alleviation. The paper is organized as follows. After the 
introduction, Section 2 discusses the literature review, the history of poverty alleviation initiatives in Nigeria, and waqf's concept and its roles in alleviating poverty. Section 3 explains the methodology of the study. Section 4 states the study's findings, while Section 5 states the conclusion.

\section{Literature Review}

\subsection{Poverty}

The concept of poverty is defined differently by scholars from different perspectives. Hence, there is no universal definition of poverty. Poverty is the inability to attain a minimum standard of living and deprivation of the fundamental necessity of life and well-being (World Bank, 1990, 2001). Ziyaviddinovna and Sagdullaevich, 2020) defined poverty as "a living condition in which an individual cannot take care of his basic needs like clothing, food, shelter, inability to meet social and economic obligations." Ajayi (2009) postulated that poverty incorporates not having sufficient food to eat, poor nutrition, low drinking water, high rate of infant mortality, unfit housing, poor environmental condition, low life expectancy, inferior educational opportunities, low level of energy consumption, inadequate health care, absence of essential infrastructure. Poverty is a lack of material and money needed to empower the people to sustain living a good life (2007). Ziyaviddinovna \& Sagdullaevich (2020) assert that poverty may deny the fulfillment of five basic human requirements in terms of religion, self, intellect or knowledge, offspring, and wealth in life a Muslim. The deprivation from poverty leads to a sense of helplessness, over-dependence, lack of opportunity, self-respect, and selfconfidence in the poor (John and Bright, 2012).

\subsection{Poverty Alleviation Programmes in Nigeria}

To alleviate the increasing poverty rate in Nigeria, successive governments have adopted different poverty alleviating programs like most other countries. In 1972 the government of Yakubu Gowon set up the National Accelerated Food Production Programme (NAFPP) and the Nigerian Agricultural and Cooperative Bank (NACB) aimed at ensuring adequate agricultural production in the country. In 1976, when General Olusegun Obasanjo took over as the head of State, "Operation Feed the Nation" was initiated (Udofia \& Mkpa, 2016). Likewise, the civilian administration headed by Alhaji Shehu Shagari introduced the "Green Revolution" in 1980 to reduce food importation by boosting crops and fiber productions in the country, among other objectives. After the overthrow of General Muhammadu Buhari by the military regime headed by General Ibrahim Babangida, the People's Bank was established to 
offer soft loans to the citizens. Babangida's administration also established the "Directorate of Food, Roads, and Rural Infrastructure" to reduce poverty to develop rural communities (Orokpo \& Mutong, 2018).

In 1997 during the regime of General Sani Abacha, attempts were also made to reduce poverty in the country by introducing the "Family Support Programme." With Nigeria's return to democracy in 1999, President Olusegun Obasanjo, the "National Poverty Eradication Programme," was also introduced to address poverty among the populace. In a renewed effort to alleviate poverty to lessen the Nigerian masses' suffering, the democratic administration of Late President Musa Ya'adua came up with a 7 point plan in 2007. One of the agendas aimed to improve living conditions for Nigerians, impoverished people. In a similar vein, President Ebele Goodluck Jonathan came up with the dual strategic programs of "Subsidy Reinvestment Empowerment Programme" in 2010 and "You Win Programme" in 2013, to create jobs for thousands of unemployed graduates and assist women to secure business grants (Tunji 2013). The current government of President Muhammad Buhari has also initiated some poverty alleviation programmers via various government initiatives, particularly in the agricultural sector.

With the exemption of the poverty alleviation programs of the current administration that are too early to be judged, other poverty alleviation initiatives have failed to translate to meaningful impacts on average Nigerians' lives (Alaro, \& Alalubosa, 2019). Besides the successive regime's efforts, different non-governmental organizations established to alleviate poverty in the country have also not yielded substantially noticeable results in poverty alleviation (Alaro \& Alalubosa, 2019). None of those mentioned above program produced tangible outcomes concerning alleviating poverty in Nigeria (Dansabo, 2015; Tunji, 2013). Achuonye (2017) asserted that poverty alleviating programs had been handled with so much noise with little or no result to show. As of 2016, 85\% of Nigerians lived in poverty (The Nation Newspaper, 2016). Thus, most Nigerians wallow in abject poverty while very few live in wealth as the menace of poverty in Nigeria has become so endemic. The failure of the government-driven poverty initiatives in Nigeria could be attributed to the possibility that such initiatives are proposed as a mere norm to achieve populist agenda despite the quantum amount of resources committed to the initiatives (AbdulKareem, AbdulGaniyy, Mahmud \& Yazid, 2020; AbdulKareem, Mahmud \& Ganiyy, 2020). To this end, this study examines the intention to establish the Islamically induced (individual and non-governmental) concept of waqf towards poverty alleviation in Oyo State, southwestern Nigeria. 


\subsection{Waqf and Poverty Alleviation}

Waqf involves holding assets, properties, or belongings in the custody of an Islamic entity meant to specifically see the needs of the poor and needy (AbdulKareem et al., 2019). Alaro and Alalubosa (2019) defined waqf as the "confinement of immovable or movable property from the ownership of the founder and the dedication of its usufruct in perpetuity to needs that may arise in the different Muslim societies in a way that it cannot be revoked, bequeathed or sold." Similarly, Mannan (2005) stated that waqf could be defined as an act of refraining from the use and disposal of any asset from which one can benefit or use it for a long time except through charity purposes. Waqf is different from Zakat and donation. Zakat is one of the essential pillars of Islam that Allah (SWT) ordained and made compulsory (wajib) on all the believing Muslims. The receivers of Zakat are clearly stated in the Quran. On the other hand, a waqf is a charitable act that is not compulsory, unlike Zakat.

The core objective of waqf is to provide for the less privileged members of the society, such as the poor, needy, orphans, widows, wayfarers, students. Also, to improve their standard of living, economic status, health, and education to make a difference between truly living and merely living (Alaro \& Alalubosa, 2019). Waqf is a pious endowment in Islam grounded on the Islamic principle of charity (Mahmood, 2006). Binti Saifuddin et al. (2014) identified that waqf effectively establishes "income-generating activities that are suitable to be operated by disabled people, single mothers, illiterate and unskilled workers. The income-generating activities will significantly benefit these individuals who might find difficulty securing other jobs (p. 174).

\subsection{Theoretical Framework and Hypotheses Development}

The study is underpinned by the theory of planned behavior (TPB) proposed by Ajzen (1991) as a revision of the Theory of Reasoned Action (TRA) (Ajzen and Fishbein, 1980). TPB gives a reason for performing a particular action (Osman et al., 2016). The theory explains human behavior from behavioral beliefs, normative beliefs, and control. The theory holds that an intention to take action is driven by three essential antecedents of attitude, subjective norm, and perceived behavioral control, which influence the choice to perform certain behaviors. The intention to act is affected by the person's perspective, social pressure (subjective norm), and the degree of control a person possesses while performing a given action (perceived behavioral control). Positive attitude and subjective norm are enhancers to perceived behavioral control that strengthens the intention to act for consideration. Nevertheless, since a good deal of 
behavior can be challenging to execute and limit volitional control, it is imperative to consider perceived behavioral control and intention (Shah Alam and Sayuti, 2011). This study expands the TPB with Religiosity and information as the antecedents of intent to establish waqf for poverty alleviation.

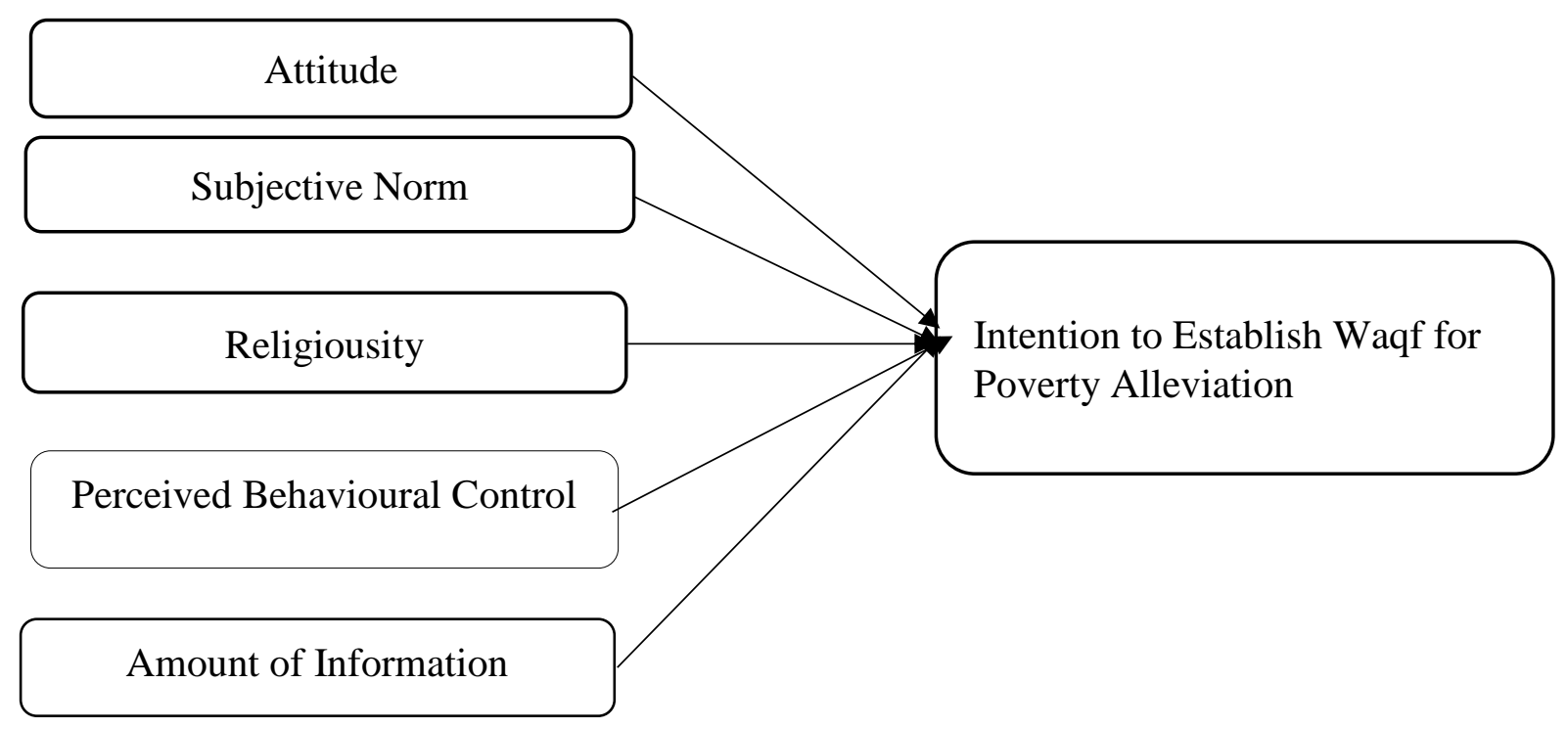

Figure 2.1 Research framework

\subsubsection{Attitude}

Attitude has long been acknowledged as a construct that guides upcoming behavior or the intention to finally see through to a specific action (Ajzen and Fishbein 1975). Besides, Ajzen (1991) affirms that attitude is characterized as the psychological tendency communicated from the favorable or unfavorable assessment of a specific substance. By implication, the more ideal a person's attitude towards the Waqf establishment, the more probable it is likely to participate in the Waqf establishment. Many studies have shown a significant association between waqf and poverty alleviation (Shih Fang, 2004; Lada et al., 2008; Amin \& Chong, 2011). Thus, we hypothesized as follow:

$\mathrm{Hl}$ : There is a significant positive relationship between attitude and intention to establish waqf for poverty alleviation.

\subsubsection{Subjective norm}

Subjective norm refers to the individual thinking that others want them to be involved in a specific behavior. Almost every individual is encouraged by deeds, advice, and others (Ajzen 
and Fishbein 1975). A subjective norm is the perceived influence of friends or relatives regarding whether specific behavior should be performed. It alludes to an individual's view of others' appropriate options to execute particular action (Ajzen, 1991). This study argues that subjective norm is a key factor that explains the intention to establish waqf to alleviate poverty, as stated in the hypothesis below:

H2: There is a significant positive relationship between subjective norm and intention to establish waqf for poverty alleviation.

\subsubsection{Perceived Behavioral Control}

Perceived Behavioural Control assumes that individuals believe that they cannot perform a specific behavior (According to Ajzen 1991). It explains the degree to which an individual has physical and mental control over their behavior and how self-confident they feel about acting (Ajzen, 2011). Hence, this study hypothesized that perceived behavioral control is predicted to have a significant relationship with the intention to establish waqf for institution poverty alleviation:

H3: There is a significant positive relationship between Perceived Behavioural Control and intention to establish waqf for poverty alleviation.

\subsubsection{Religiosity}

Religiosity refers to how believers practice their religious faith in their commitment to daily life (Amin et al., (2011). Legenhausen (2016) defines Religiosity as the degree to which a person follows their religious values, practices, and beliefs and practices them daily. And the obligation to religious activities is called Religiosity. Muslims with a higher level of Religiosity would participate more in establishing waqf than those with low Religiosity. Therefore, when an individual is committed religiously, his behavior is likely based on Religiosity than just religious affiliation (Ahmad et al., 2008). Religiosity as a concept has been applied in psychology and sociology fields, and it is yet to be fully explored in waqf's research (McDaniel \& Burnett 1990; Ahmad et al. 2008). Several studies have reported evidence suggesting that religion will influence behavior (Abdullah \& Abd-Majid, 2003; Mokhlis, 2009). However, few scholars have considered the importance of Religiosity in participating in particular to waqf. This study finds Religiosity as one factor influencing the intention to establish waqf among wealthy Muslims. Therefore, it is hypothesized that:

H4: There is a significant positive relationship between Religiosity and intention to establish waqf for poverty alleviation. 


\subsubsection{Amount of information}

According to the Merriam-Webster Dictionary (1828), information can be defined as knowledge that one obtains about something or someone or knowledge gained from inquiry instruction or study. The importance of information in accepting any new things cannot be over-emphasized. It is more so in favor of religious activities like waqf. This construct is based on the fact that the availability of information helps to enhance understanding of the usefulness of Waqf among Muslims. Pikkarainen et al. (2004) have argued that the quantity of available data will determine the level of acceptance of certain products. Minimal studies have linked the importance of information available to the behavior of a particular system. This position seems to have been established by Sathye (1999), who also confirmed the significant relationship between the information and installing a specific plan. Contrarily, Ramayah et al. (2006) found no meaningful relationship between the amount of information and intention to use internet banking. Therefore, it can be argued that the amount of information on waqf available to wealthy Muslim individuals will determine whether they would establish waqf to alleviate poverty or not. The hypothesis is thus stated as follow:

H5: There is a significant positive relationship between the amount of information and the intention to establish waqf for poverty alleviation.

\section{Research Method}

This study used a cross-sectional design conducted through a survey. The instrument of data collection is an open-ended questionnaire with a 5-point Likert response ranging from strongly disagree (1), disagree (2), neutral (3), agree (4), and strongly agree (5). The study's questionnaire items were adapted from the previous study (see Table l). The study population was obtained from the Secretariats of all the thirty-three Local Government Oyo State covering from masjid that performs Friday and daily prayers with an average number of five hundred (500) Islamic scholars (Alfas) across the thirty-three local government of Oyo State, Nigeria. The sample size was selected from the population using Krejcie and Morgan's (1970) Table to determine sample size. Based on the table, the minimum sample is 217 . To have a representative sample from all the 33 local governments, a proportionate random sampling was used. All the Islamic scholars (Alfas) obtained from the Secretariats of the thirty-three Local Government from masjid that performs Friday. Daily prayers were represented proportionately to the population size of scholars from the local governments (see Appendix 1). The study utilized the Statistical Package for Social Science (SPSS) Software to analyze 
both inferential and descriptive statistics. Hypotheses were tested with multiple linear regression techniques.

Table 3. 1 The Measurement of constructs

\begin{tabular}{|c|c|c|}
\hline Constructs & No. of items & Sources \\
\hline Attitude & 5 & $\begin{array}{l}\text { Rmayah et al. (2009) and Gopi and Ramayah } \\
\text { (2007) }\end{array}$ \\
\hline Subjective Norm & 3 & $\begin{array}{c}\text { Rmayah et al. (2009) and Gopi and Ramayah } \\
\text { (2007) }\end{array}$ \\
\hline $\begin{array}{l}\text { Perceived Behavioural } \\
\text { Control }\end{array}$ & 4 & Shih and Fang (2004) \\
\hline Religiosity & 6 & Adapted from Faiz (2014) \\
\hline $\begin{array}{l}\text { Amount of Information } \\
\text { Dependent Variable }\end{array}$ & 4 & Amin et al. (2014) \\
\hline $\begin{array}{l}\text { Establishment of Waqf } \\
\text { as a way of Poverty } \\
\text { Alleviation }\end{array}$ & 5 & $\begin{array}{l}\text { Ramayah et al. (2009) } \\
\text { and Gopi and Ramayah (2007) }\end{array}$ \\
\hline
\end{tabular}

An overview reveals that Oyo State is one of the South Western states in Nigeria, with over five million. Oyo state has an absolute poverty rate of $51.8 \%$ for poor people and a relative poverty rate of $60.7 \%$ for poor people (National Population Commission, 2010). It has thirtythree Local Governments area councils. Oyo State is one of Yorubaland and Lagos, Ekiti, Ondo, Ogun, Osun. The State is one of the oldest states in Nigeria. The State bounded on the north side by Kwara state, on the east side by Osun state, south by Ogun State and, on the west by the Republic of Benin. Oyo State covers around 28454 square kilometers of landmass (Adeyonu Oni, Okoruwa \& Omonona 2012).

\section{Result}

\subsection{Response Rate}

A total of 218 questionnaires were retrieved and used in the data analysis. This finding indicates a response rate of $72.6 \%$ out of the 300 questionnaires administered. From Table 4.1, Respondents' Demographic Profile indicates that out of a total of 218 respondents, male respondents (96.3\%) dominated the female (3.7). Respondents' age distribution showed that 39.9 were less than 30 years of age; those between 30 and 39 were 20.2\%; 40-49 were 10. 6\%; 50-59 were 14.2\%; while those between 60 and above constitute 15.1\%. Married respondents were $48.2 \%$; single respondents were $26.6 \%$, while other marital status accounted for $25.5 \%$. Based on the level of education, respondents with primary education amounted to $43.6 \%$ of the sample; those with secondary education constituted 19.3\%. Respondents with tertiary 
institution qualifications took $18.3 \%$ of the sample population, while others accounted for $26.1 \%$. On the basis of respondents' occupation, civil servants are $44.5 \%$; those in business are 12.4\%; farming (18.3\%); self-employed (5.5\%); academics/teachers (19.3\%).

Table 4.1 Demographic Data of respondents Profiles

\begin{tabular}{|c|c|c|}
\hline & Frequency & Percent (\%) \\
\hline \multicolumn{3}{|l|}{ Gender } \\
\hline Male & 210 & 96.3 \\
\hline Female & 8 & 3.7 \\
\hline \multicolumn{3}{|l|}{ Age } \\
\hline Less than 30 & 87 & 39.9 \\
\hline $30-39$ & 44 & 20.2 \\
\hline $40-49$ & 23 & 10.6 \\
\hline $50-59$ & 31 & 14.2 \\
\hline 60 and above & 33 & 15.1 \\
\hline \multicolumn{3}{|l|}{ Marital status } \\
\hline Married & 105 & 48.2 \\
\hline Single & 58 & 26.6 \\
\hline Others & 55 & 25.2 \\
\hline \multicolumn{3}{|l|}{ Level of Education } \\
\hline Primary & 95 & 43.6 \\
\hline Secondary & 26 & 19.3 \\
\hline Tertiary institution & 40 & 18.3 \\
\hline Others & 57 & 26.1 \\
\hline \multicolumn{3}{|l|}{ Occupation } \\
\hline Civil servant & 97 & 44.5 \\
\hline Business & 27 & 12. 4 \\
\hline Farming & 40 & 18.3 \\
\hline Student & - & - \\
\hline Retired & - & - \\
\hline Unemployed & - & \\
\hline Self-employed & $\overline{12}$ & $5 . \overline{5}$ \\
\hline Academic/teacher & 42 & 19.3 \\
\hline Others & & \\
\hline
\end{tabular}

\subsection{Descriptive statistics of constructs}

Table 4.2 presents the mean and standard deviation of the study variables, which fell between 4.54 and 6.760. This information indicated that the variables' scores fell between moderately high (3.0) to highest (7.0). Attitude had the highest mean score (6.76) with a standard deviation of 0.72 , Perceived behavioral control had the high mean score also (5.94) with a standard deviation of 0.97 , Religiosity had the medium mean score (5.62) with a standard deviation of 0.98 . The amount of information had the medium mean score (5.51) with 
a standard deviation of 1.06, while the Subjective norm had the lowest mean score (4.54) with a standard deviation of 0.94 .

Table 4.2 Descriptive Statistics for the variables

Descriptive Statistics for Latent Variables

\begin{tabular}{lccr}
\hline Constructs & No. of Items & Mean & St. Deviation \\
PBC & 4 & 5.94 & 0.97 \\
SUB-NORM & 3 & 4.54 & 0.94 \\
INFO & 4 & 5.51 & 1.06 \\
ATT & 5 & 6.76 & 0.72 \\
REL & 6 & 5.62 & 0.98 \\
WA2F & 5 & 4.90 & 0.96 \\
\hline
\end{tabular}

Note: $\mathrm{PBC}=$ perceived Behavioural Control, SUB-NORM= Subjective Norm, INFO= Amount of Information, ATT= Attitude, REL= Religiosity, Waqf.

\subsection{Reliability Test of the Constructs}

This test ensures the reliability of the collected data. According to Sekaran \& Bougie (2003), all data must be tested to verify that the results are reliable. From the Sekaran \&\& Bougie (2003) point of view, data with reliability of 0.5 and above is considered reliable for further analysis. The reliability of the data collected was shown in Table: 4.3, The Cronbach's alpha ranges between .633 to .854 , signifying that the data collected are reliable and, thus, can be concluded to have internal consistency.

Table 4.3 Reliability Statistics

\begin{tabular}{lcr}
\hline Measure & No. of Items & Cronbach's Alpha \\
\hline Attitude & 5 & .807 \\
Subjective Norm & 3 & .721 \\
Perceived Behavioural Control & 4 & .800 \\
Religiousity & 6 & .854 \\
Amount of information & 3 & .633 \\
\hline
\end{tabular}

Attitude is found to be .807 ; the subjective norm is found to be .721; perceived behavioral control is found to be .800 ; Religiosity is found to be .854 and amounts of information variable is .633, although an item (info 3) was deleted from this variable, item 3 was deleted to achieve the acceptable level of Cronbach Alpha value which is 0.6 based on Sekaran's (2003). With item 3, the Cronbach alpha does not reach sufficient loadings. So, it was deleted to get the acceptable loading. 


\subsection{Correlation statistics and multicollinearity}

Correlation analysis was used to examine the degree of relationship among the independents (Attitude, Subjective Norm, Perceived Behavioural Control, Religiosity and Amount of Information) and a dependent variable examined in this research work. According to Cohen (1988), the coefficient of correlation (r) is small if the value range between 0.1 and 0.29 ; it is medium if $\mathrm{r}$ is between 0.3 and 0.49 , and large if $\mathrm{r}$ is from 0.5 to 1.0. The analysis results show that the variables under investigation are positively correlated, meaning that they have positive relationships. Table 4.4 shows the correlation analysis of the sample of the study. It can be deduced that all the independent variables (Attitude, Subjective Norm, Perceived Behavioural Control, Religiosity, and Amount of Information) are positively correlated with others. It also positively correlates with the dependent variable (intention to establish waqf for poverty alleviation).

The overall conclusion that can be discerned from the above table is that the connection between this study's variables is not so strong as to lead to a multicollinearity threat. Also, Durbin Watson's value for this study is 2.316, which falls between the accepted range of 1.5 and 2.5 is obtained. According to Lukacs, Burnham, and Anderson (2010), the purpose of checking Durbin Watson is to investigate the issue of multicollinearity. And it has been demonstrated that this study is free from multicollinearity that might occur at random as the Durbin Watson value falls within the accepted value of 1.5 to 2.5 . 
Table 4.4 Correlations

\begin{tabular}{|c|c|c|c|c|c|c|c|}
\hline & & PBC & ATT & INFO & NORM & REL & WAQAF \\
\hline PBC & $\begin{array}{c}\text { Pearson } \\
\text { Correlation } \\
\text { Sig. (2- } \\
\text { tailed) }\end{array}$ & 1 & & & & & \\
\hline ATT & $\begin{array}{l}\text { Pearson } \\
\text { Correlation } \\
\text { Sig. (2- } \\
\text { tailed) }\end{array}$ & $\begin{array}{r}.458^{* *} \\
.000\end{array}$ & 1 & & & & \\
\hline \multirow[t]{2}{*}{ INFO } & $\begin{array}{l}\text { Pearson } \\
\text { Correlation }\end{array}$ & $.450^{* *}$ & $.282^{* *}$ & 1 & & & \\
\hline & $\begin{array}{l}\text { Sig. (2- } \\
\text { tailed) }\end{array}$ & .000 & .000 & & & & \\
\hline \multirow[t]{2}{*}{ NORM } & $\begin{array}{l}\text { Pearson } \\
\text { Correlation }\end{array}$ & $.332^{* * *}$ & $.267^{* *}$ & $.645^{* *}$ & 1 & & \\
\hline & $\begin{array}{l}\text { Sig. (2- } \\
\text { tailed) }\end{array}$ & .000 & .000 & .000 & & & \\
\hline \multirow[t]{2}{*}{ REL } & $\begin{array}{l}\text { Pearson } \\
\text { Correlation }\end{array}$ & $.404^{* *}$ & $.225^{* *}$ & $.734^{* *}$ & $.594^{* *}$ & 1 & \\
\hline & $\begin{array}{l}\text { Sig. (2- } \\
\text { tailed) }\end{array}$ & .000 & .001 & .000 & .000 & & \\
\hline \multirow[t]{2}{*}{$W A Q F$} & $\begin{array}{l}\text { Pearson } \\
\text { Correlation }\end{array}$ & $.569^{* *}$ & $.427^{* *}$ & $.530^{* *}$ & $.474^{* *}$ & $.508^{* *}$ & 1 \\
\hline & $\begin{array}{l}\text { Sig. (2- } \\
\text { tailed) }\end{array}$ & .000 & .000 & .000 & .000 & .000 & \\
\hline
\end{tabular}

**. Correlation is significant at the 0.01 level (2-tailed).

Note: $\mathrm{PBC}=$ perceived Behavioural Control, $\mathrm{SUB}-\mathrm{NORM}=$ Subjective Norm, $\mathrm{INFO}=$ Amount of Information, ATT= Attitude, REL= Religiosity, Waqf.

\subsection{Regression Analysis}

The regression results displayed in Table 4.5 show that the value of $\mathrm{r}^{2}=.460$ and $\mathrm{F}$ value of 38.002 signifies that the variable is under consideration (attitude, subjective norm, perceived behavioral control, Religiosity, and amount of information) altogether significantly explain the model. However, they can only explain $46 \%$ of the variance of waqf's establishment for poverty alleviation.

Table 4.5 Regression Analysis

\begin{tabular}{llc}
\hline Variable & B & Sig. \\
\hline Attitude & .169 & .003 \\
Subjective Norm & .144 & .034 \\
Perceived Behavioural Control & .322 & .000 \\
Religiousity & .161 & .035 \\
Amount of Information & .127 & .122 \\
$\mathrm{R}$ & .687 & \\
$\mathrm{R}^{2}$ & .473 & \\
\hline Note: PBC= perceived Behavioural Control, SUB-NORM= Subjective Norm, INFO= Amount of Information, ATT= \\
Attitude, REL= Religiosity, Waqf.
\end{tabular}


Table 4.6 Regression Analysis Testing for $\mathrm{H}_{1} \mathrm{H}_{2} \mathrm{H}_{3} \mathrm{H}_{4} \mathrm{H}_{5} \mathrm{H}_{6}$

\begin{tabular}{lcccc}
\hline Variables & Hypotheses & Beta $(\beta)$ & T- Score & Sig \\
\hline (Constant) & & & .023 & .000 \\
Attitude & $\mathrm{H}_{1}$ & .169 & 2.982 & .003 \\
Subjective Norm & $\mathrm{H}_{2}$ & .144 & 2.131 & .034 \\
Perceived Behavioural Control & $\mathrm{H}_{3}$ & .322 & 5.270 & .000 \\
Religiosity & $\mathrm{H}_{4}$ & .161 & 2.122 & .035 \\
Amount of Information & $\mathrm{H}_{5}$ & .127 & 1.555 & .122 \\
R Square & .473 & & & \\
Adjusted R Square & .460 & & & \\
F Value & 38.002 & & & \\
Durbin Watson & 2.316 & & & \\
\hline
\end{tabular}

Table 4.6 indicates the results of samples surveyed in the study the significance level of factors influencing the establishment of the Waqf institution as a way of poverty alleviation. From this table, it is observed that all relationships are the significant. $\mathrm{Hl}(\beta=.169, t=2.982)$; $\mathrm{H} 2((\beta=.144, t=2.131) ; \mathrm{H} 3(\beta=.322, t=5.270) ; \mathrm{H} 4(\beta=.161, t=2.122) ; \mathrm{H} 5(\beta=.127, t=1.555)$. The results show that all hypotheses are positively significant except, $\mathrm{H} 5$.

\section{Conclusion}

The study examines the influence of attitude, subjective norm, perceived behavioral control, Religiosity, and information on establishing Waqf in Oyo State, Nigeria. The study found that the entire antecedents are significantly influential in establishing waqf in line with the theory of planned behavior. The study theoretically contributes to the stream of literature that affirms the idea's efficacy on the behavioral intention from the Islamic Shariah perspective, focusing on waqf as an instrument of poverty alleviation. To this end, the study recommends that the horizon of poverty alleviation drive needs to pay special attention to waqf in addition to governmental efforts. The findings also reveal that integrating waqf into the poverty alleviation drive will benefit all stakeholders irrespective of religious backgrounds. Lastly, the government will benefit significantly from it as poverty has been a threat to the development of any nation could be challenged from a broader perspective. Thus, the achievement of poverty alleviation objectives would be strengthened.

\section{References}


Abdullah, N., \& Abd-Majid, M. S. A. (2003). The Influence of Religiosity, Income, and Consumption on Saving Behavior: The Case of International Islamic University Malaysia (IIUM). Jurnal Iqtisad, 4(1), 1-11.

AbdulKareem, I. A., Ogunbado, A. F., AbdulGaniyy, A., \& Mahmud, M. S. (2019). Factors Motivating the Establishment of Waqf Institution towards Poverty Alleviation among Muslim Ummah in Oyo State, South West, Nigeria. Jurnal Manajemen Bisnis (JMB), 32(1), 4l-59.

AbdulKareem, I. A., AbdulGaniyy, A., Mahmud, M. S., \& Yazid, A. S. (2020). Alternative Way to Reducing Poverty and Inequality in Nigeria from an Islamic Perspective. Journal of Islamic Banking and Finance, 37(2), 73-83.

AbdulKareem, I. A., Mahmud, M. S., \& AbdulGaniyy, A. (2020). Thematic Review of Sukuk Ijarah Issued in Nigeria: An Opportunity for Economic Development. Jurnal Iqtisaduna, $1(1), 61-80$.

Adeyonu, A. G., Oni, O. A., Okoruwa, V. O., \& Omonona, B. T. (2012). Seasonality in Poverty Level of Rural Farming Households in Oyo State Nigeria. ARPN Journal of Agricultural and Biological Science, 7(8) 570-575.

Achuonye, K. A. (2017). Education in Nigeria for value re-orientation, poverty eradication, and national development. A paper was presented at the 19th Nafak Conference at the University of Port Harcourt, Choba Rivers State, Nigeria. 13th-17th March.

Ahmad, W. M. W., Rahman, A. A., Ali, N. A., \& Seman, A. C. (2008). Religiosity and banking selection criteria among Malays in Lembah Klang. Shariah Journal, 16(2), 279-304.

Ajzen, I. (2011). The theory of planned behavior: Reactions and reflections. Psychology \& Health, 26(9), $1113-1127$

Ajayi, A.R. (2009). The Role Expectations of Agricultural Extension in Poverty Alleviation in a Democratic and Deregulated Economy in J.U Agbamu (ed) Perspectives in Agricultural Extension and Rural Development, Asaba, Springfield Publishers.

Ajzen, I., \& Fishbein, M. (1980). Understanding attitudes and predicting social behavior. Englewood Cliffs, NJ: Prentice-Hall.

Ajzen, I. and Fishbein, M. (2000). Attitudes and the attitude-behavior relation: reasoned and automatic processes, in Stroebe, W. and Hewstone, M. (Eds), European Review of Social Psychology, Wiley, New York, NY, 1-28.

Alaro, A. A. M., \& Alalubosa, A. H. (2019). Potential of Sharī'ah compliant microfinance in alleviating poverty in Nigeria. International Journal of Islamic and Middle Eastern Finance and Management. 115-129.

Ali, I. B. (2009). Waqf: A sustainable development institution for Muslim communities. Takaful T \& T\&T Friendly Society, Trinidad and Tobago is available at www. takaafultt. Org.

Amin, H., Rahim Abdul Rahman, A., \& Abdul Razak, D. (2014). Customer acceptance of Islamic home financing. International Journal of Housing Markets and Analysis, 7(3), 307332.

Amin, H., \& Chong, R. K. (2011). Is the theory of reasoned action valid for Ar-Rahnu? An empirical investigation. Australian Journal of Basic and Applied Sciences, 5(10), 716-726.

Binti Saifuddin, F., Kayadibi, S., Polat, R., Fidan, Y., \& Kayadibi, O. (2014). The Role of cash Waqf in poverty alleviation: Case of Malaysia. International Journal of Business, Economics, and Law, 4 (1), 171- 179.

Dansabo, M. T. (2015). Assessing the developmental impact of poverty eradication programs in Sokoto State, Nigeria. The Nigerian Journal of Sociology and Anthropology, 13(1). 
Chabbal, A. Y. (2020). Waqf and Entrepreneurship: An Ignored Mechanism for Modern Economic Development in Nigeria. Journal of African Sustainable Development, 20(2) 2218-8777.

Cohen, M. A. (1988). Some new evidence on the seriousness of the crime. Criminology, 26(2), 343-353.

Gopi, M., \& Ramayah, T. (2007). Planned behavior theory's application in predicting intention to trade online: Some evidence from a developing country. International Journal of Emerging Markets, 2(4) 348-360.

John, O. A., \& Bright, O. O. (2012). Poverty and youth unemployment in Nigeria, 1987-2011. International Journal of Business and Social Science, 3(20).

Kazeem, Y. (2018). Nigeria is set to stay the world's poverty capital for at least a generation, Quartz Africa. https:/qz.com/africa/1421543/nige rias-poverty-crisis-isworseningoxfam-world-bank-data/

Krejcie, R. V., \& Morgan, D. W. (1970). Table for determining sample size from a given population. Educational and Psychological Measurement, 30(3), 607-610.

Lada, C. J., Muench, A. A., Rathborne, J., Alves, J. F., \& Lombardi, M. (2008). The nature of the dense core population in the Pipe Nebula: thermal cores under pressure. The Astrophysical Journal, 672(1), 410.

Legenhausen, M. (2016). A Muslim's non-reductive religious pluralism. In Islam and Global Dialogue (pp. 71-94). Routledge.

Lukacs, P. M., Burnham, K. P., \& Anderson, D. R. (2010). Model selection bias and Freedman's paradox. Annals of the Institute of Statistical Mathematics, 62(1), 117-125.

Mannan M.A (2005) The Role of Waqf in Improving the Ummah Welfare. Presentation at the International Seminar on Islamic Economics as a Solution. Organized by the Indonesian Association of Islamic Economists and Muamalat Institute, Jakarta. Medan, Indonesia.

McDaniel, S. W., \& Burnett, J. J. (1990). Consumer religiosity and retail store evaluative criteria. Journal of the Academy of Marketing Science, 18(2), 101-112.

Mokhlis, S. (2009). Relevancy and measurement of Religiosity in consumer behavior research. International Business Research, 2(3), 75.

Obikeze, O. S. A., \& Ananti, M. O. (2015). The Challenges of Ending Rural Poverty: An Appraisal of the National Poverty Eradication Programme (NAPEP). Journal of Policy and Development Studies, 289(1851), 1-11.

Ogunna, A.E.C. (2007). Basic issues in community development and local government. Owerri Versatile Publishers.

Orokpo, O. F., \& Mutong, S. M. (2018). Nigeria's Raising Poverty Profile Amidst Poverty Alleviation Programmes: Interrogating the Paradox. International Journal of Innovative Development and Policy Studies, 6(2), 109-116.

Osman, S., Mati, I., Ahmad, J., \& Haji-Othman, Y., (2015) Unlocking Value of Waqf Property Using Hibah Mudharabah: A Case study of Commercial Buildings in Kedah, Malaysia, International Journal of Development Research, 5(05), 4294-4299.

Pikkarainen, T., Pikkarainen, K., Karjaluoto, H., \& Pahnila, S. (2004). Consumer acceptance of online banking: An extension of the technology acceptance model. Internet Research, 14(3), 224-235.

Ramayah, T., Rouibah, K., Gopi, M., \& Rangel, G.J. (2009). A decomposed theory of reasoned action explains the intention to use Internet stock trading among Malaysian investors. Computers in Human Behavior, 25(6), 1222-1230.

Ramayah, T., Md-Taib, F., and Ling, K.P. (2006). Classifying users and non-users of internet banking in northern Malaysia. Journal of Internet Banking and Commerce, 11(2), 1-13. 
Sathye, M. (1999). Adoption of Internet banking by Australian consumers: an empirical investigation. International Journal of bank marketing, 17(7), 324-334.

Sekaran, U. (2003). Research methods for business: A skill-building approach. John Wiley \&e Sons.

Sekaran, U., \& Bougie, R. (2003). Research methodology for business. A skill-building approach. John Wiley \& Sons.

Shah Alam, S., \& Mohamed Sayuti, N. (2011). Applying the Theory of Planned Behavior (TPB) in halal food purchasing. International Journal of Commerce and Management, 21(1), 8-20.

Shih, Y. Y., \& Fang, K. (2004). A decomposed theory of planned behavior to study Internet banking in Taiwan. Internet Research, 14(3), 213-223.

Tagoranao, M. S., \& Gamon, A. D. (2019). Understanding the Religious Rights of the Muslims in the Philippines: A Catalyst for Peace and Justice (Kefahaman tentang Hak Beragama Orang Islam di Filipina: Pemangkin untuk Keamanan dan Keadilan). Journal of Islam in Asia, 16(1), 204-220.

The nation newspaper (2016). Eighty-five percent of Nigerians live in poverty - Ngige. Retrieve online on 25 April 2020 from http://thenationonlineng.net/85-percent-nigerians-livepoverty-ngige/

Tunji, S.T., (2013), "Islamic banking as a panacea for economic instability in Nigeria," Nigerian Chapter of Arabian Journal of Business and Management Review, l(3).

Udofia, N., \& Mkpa, P. (2016). An assessment of the impediments to the National Poverty Eradication Programme (NAPEP's) objectives. IOSR Journal of Humanities and Social Science, 21(3), 05-13.

World Bank (1990). Poverty: World Development Indicators. World Development Report. Retrieved online on 15th April 2020 from https://openknowledge.worldbank.org/bitstream/handle/10986/5973/WDR\%2 01990\%20-\%20English.pdf? sequence $=5 \&$ is Allowed $=y$.

World Bank (2001). World Development Report, attacking poverty. Retrieved online on 15 April $2020 \quad$ from http://www.ssc.wisc.edu/ walker/wp/wpcontent/uploads/2012/10/wdr2001.pdf

Yusuff, J. A., \& Noor Aziza, C. E. (2013). Alleviation of poverty among OIC countries through sadaqat, cash waqf, and public funding. International Journal of Trade, Economics, and Finance, 4(6), 403.

Ziyaviddinovna, M. M., \& Sagdullaevich, K. K. (2020). Poverty reduction by the Islamic waqf system. Journal of Critical Reviews, 7(4), 68-73. 
Appendix Number of General Mosques in the State

\begin{tabular}{|c|c|c|}
\hline S/No & Local government areas & Mosques/ Islamic scholars \\
\hline 1 & AFIJIO & 15 \\
\hline 2 & AKINYELE & 20 \\
\hline 3 & ATIBA & 20 \\
\hline 4 & ATISBO & 18 \\
\hline 5 & EGBEDA & 24 \\
\hline 6 & IBADAN NORTH & 22 \\
\hline 7 & IBADAN NORTH EAST & 25 \\
\hline 8 & IBADAN NORTH WEST & 25 \\
\hline 9 & IBADAN SOUTH EAST & 25 \\
\hline 10 & IBADAN SOUTH WEST & 21 \\
\hline 11 & IBARAPA CENTRAL & 18 \\
\hline 12 & IBARAPA EAST & 15 \\
\hline 13 & IBARAPA NORTH & 13 \\
\hline 14 & IDO & 13 \\
\hline 15 & IREPO & 19 \\
\hline 16 & ISEYIN & 24 \\
\hline 17 & ITESIWAJU & 18 \\
\hline 18 & IWAJOWA & 17 \\
\hline 19 & KAJOLA & 20 \\
\hline 20 & LAGELU & 23 \\
\hline 21 & OGO OLUWA & 18 \\
\hline 22 & OGBOMOSO & 17 \\
\hline 23 & OGBOMOSO SOUTH & 16 \\
\hline 24 & OLORUNSOGO & 18 \\
\hline 25 & OLUYOLE & 25 \\
\hline 26 & OORELOPE & 18 \\
\hline 27 & ONA ARA & 19 \\
\hline 28 & ORIRE & 17 \\
\hline 29 & OYO EAST & 20 \\
\hline 30 & OYO WEST & 20 \\
\hline 31 & SAKI EAST & 21 \\
\hline 32 & SAKI WEST & 20 \\
\hline 33 & SURULERE & 19 \\
\hline
\end{tabular}

Based on available information gathered by the researcher by the time of the conduct, the study 